\title{
Charakterystyka prawno-podatkowa opłaty za gospodarowanie odpadami komunalnymi i jej opodatkowanie podatkiem od towarów i usług
}

\section{Wprowadzenie}

Nowelizacja ustawy z dnia 13 września 1996 r. o utrzymaniu czystości i porządku w gminach ${ }^{1}$, która weszła w życie z dniem 1 stycznia 2012 r., przemodelowała zasady gospodarowania odpadami komunalnymi. Przeniosła bowiem znaczną część obowiązków dotyczących odbioru odpadów na gminy, którym m.in. nakazano utworzenie obligatoryjnego systemu gospodarowania odpadami komunalnymi, stosowanego wobec właścicieli nieruchomości, na których zamieszkują mieszkańcy².

Jednym $\mathrm{z}$ najistotniejszych rozwiązań zastosowanych w nowym modelu było przejęcie przez gminy obowiązku zawierania umów o odbiór odpadów z przedsiębiorcami odbierającymi odpady komunalne ${ }^{3}$. Koszty funkcjonowania obligatoryjnego systemu gospodarowania odpadami komunalnymi pokrywane

${ }^{1}$ T.j. Dz.U. 2020, poz. 1439 ze zm. Wspomniana nowelizacja została dokonana na podstawie ustawy z dnia 1 lipca 2011 r. o zmianie ustawy o utrzymaniu czystości i porządku w gminach oraz niektórych innych ustaw (Dz.U., nr 152, poz. 897 ze zm.); dalej: u.u.c.p.g.

${ }^{2}$ Zarządzanie nieruchomościami. Red. Z. Bukowski. Wolters Kluwer, Warszawa 2013, rozdział 9.2.

${ }^{3}$ G. Radecki: Opłata za gospodarowanie odpadami komunalnymi. „Przegląd Prawa Publicznego" 2012, nr 12, s. 19-20. 
są z opłat za gospodarowanie odpadami komunalnymi ${ }^{4}$. Wprowadzenie owych opłat - często nieprawidłowo określanych mianem „podatku śmieciowego” wywołało szereg kontrowersji, dotyczących nie tylko ich kwalifikacji jako konkretnej należności publicznoprawnej, lecz także opodatkowania samych opłat.

Dziś aktualny pozostaje zwłaszcza problem opodatkowania opłat podatkiem od towarów i usług, również w przypadkach, gdy opłata przenoszona jest przez właścicieli nieruchomości na najemców, w tym w ramach czynszu. Zagadnienie to wciąż stanowi przedmiot licznych interpretacji organów podatkowych, wydawanych na wniosek m.in. gmin, które są żywo zainteresowane tematem.

Niniejszy artykuł porusza kwestie prawno-podatkowej istoty opłat za gospodarowanie odpadami komunalnymi, ich kwalifikacji jako podatku lub opłaty, a także ewentualnego opodatkowania opłat za gospodarowanie odpadami komunalnymi podatkiem od towarów i usług. Autor odnosi się przy tym wyłącznie do opłat związanych z obligatoryjnym (gminnym) systemem gospodarowania odpadami komunalnymi, dotyczącym nieruchomości, na których zamieszkują mieszkańcy. Poza zakresem rozważań pozostają opłaty dobrowolne, które mogą być wprowadzane uchwałami rad gmin wobec nieruchomości, na których nie zamieszkują mieszkańcy.

\section{Prawno-podatkowa kwalifikacja opłaty za gospodarowanie odpadami komunalnymi}

\section{Istota opłaty za gospodarowanie odpadami komunalnymi}

Od 1 stycznia 2012 r. gminy są obowiązane do zorganizowania odbioru odpadów komunalnych od właścicieli nieruchomości, na których zamieszkują mieszkańcy ${ }^{5}$. Aby zapewnić środki na funkcjonowanie systemu gospodarowania owymi odpadami, właściciele nieruchomości zobligowani zostali do ponoszenia na rzecz gminy, na której terenie są położone ich nieruchomości, opłat za gospodarowanie odpadami komunalnymi 6 .

Obowiązek uiszczania opłat spoczywa na właścicielach nieruchomości, jak również na współwłaścicielach, użytkownikach wieczystych oraz jednostkach organizacyjnych i osobach posiadających nieruchomość w zarządzie lub użytkowaniu, a także na innych podmiotach władających nieruchomością ${ }^{7}$. Wskazuje

\footnotetext{
${ }^{4}$ Dalej też: opłaty; art. 6r ust. 2 u.u.c.p.g.

5 Art. 6c ust. 1 u.u.c.p.g.

${ }^{6}$ Art. 6 h ust. 1 u.u.c.p.g.

${ }^{7}$ Art. 2 ust. 1 pkt 4 u.u.c.p.g.
} 
się, że w przypadku, w którym za właściciela nieruchomości w rozumieniu art. 2 ust. 1 pkt 4 u.u.c.p.g. mógłby zostać uznany więcej niż jeden podmiot, obowiązek uiszczania opłat powinien obciążać podmiot faktycznie nią władają$\mathrm{cy}^{8}$. Sugerowałoby to, że podmiotami obowiązanymi do uiszczania opłaty mogą być również najemcy ${ }^{9}$, kwestia ta jednak wciąż budzi kontrowersje ${ }^{10}$. Rekomendowane zatem wydaje się - przewidziane w art. 2 ust. $2 a$ u.u.c.p.g. - uprawnienie do jej uregulowania za pośrednictwem pisemnej umowy zawartej pomiędzy „właścicielami” w rozumieniu art. 2 ust. 1 pkt 4 u.u.c.p.g. ${ }^{11}$

Co do zasady wysokość opłat dotyczących nieruchomości, na których zamieszkują mieszkańcy, stanowi wypadkową stawki opłaty oraz jednego z trzech kryteriów (podstaw) ustalania owej stawki ${ }^{12}$. Może nim być:

a) liczba mieszkańców zamieszkujących daną nieruchomość; lub

b) ilość zużytej wody z danej nieruchomości; lub

c) powierzchnia lokalu mieszkalnego ${ }^{13}$.

Zarówno określenie wysokości stawki, jak i wybór kryterium branego pod uwagę przy jej ustalaniu pozostawiono decyzji rady gminy ${ }^{14}$, która jest wszakże ograniczona maksymalnymi stawkami opłat wynikającymi wprost $\mathrm{z}$ ustawy ${ }^{15}$. Na terenie całej gminy może być przyjęte wyłącznie jedno kryterium, niezależnie od faktycznej różnorodności nieruchomości położonych w jej obrębie oraz podziału gminy na sektory odbierania odpadów komunalnych ${ }^{16}$. W kompetencjach rady gminy pozostawiono również prawo do ustalenia jednej stawki od gospodarstwa domowego ${ }^{17}$.

W przypadku nieruchomości, na której zamieszkują mieszkańcy, obowiązek ponoszenia opłaty za gospodarowanie odpadami komunalnymi powstaje za

${ }^{8}$ Wyrok WSA w Poznaniu z dnia 21 listopada 2018 r., sygn. I SA/Po 510/18, LEX nr 2587089.

${ }^{9}$ M. Hadel: Podmiot zobowiazany do ponoszenia opłat za gospodarowanie odpadami komunalnymi. Glosa aprobująca do wyroku Wojewódzkiego Sądu Administracyjnego w Poznaniu $z$ dnia 21 listopada 2018 r., I SA/Po 510/18. „Finanse Komunalne” 2019, nr 9, s. 66-78.

${ }^{10}$ W. Szwaczko: Kto jest wtaścicielem nieruchomości? „Przegląd Komunalny” 2011, nr 10, s. 34 .

${ }^{11}$ A. Kiepas-Kokot: Utrzymanie porzadku i czystości w gminie. Gospodarowanie odpadami komunalnymi. Komentarz. Legalis 2017/el., komentarz do art. 6h, nt. I.1.

12 A. Jezierska-Markocka, M. Markocki: Ustawa o utrzymaniu czystości i porzadku w gminach. Komentarz. Legalis 2019, komentarz do art. 6j, nt. 1.

${ }_{13}$ Art. 6j ust. 1 u.u.c.p.g.

${ }^{14}$ Art. 6k ust. 1 pkt 1 u.u.c.p.g.

${ }_{15}$ Art. 6k ust. 2a u.u.c.p.g.

${ }^{16}$ M. Błachut: Wybrane problemy stanowienia aktów prawa miejscowego, dotyczacych opłaty za gospodarowanie odpadami komunalnymi. „Nowe Zeszyty Samorządowe” 2013, nr 1, s. 1.

${ }^{17} \mathrm{~K}$. Gawrońska: Kompetencje rady gminy w zakresie zmiany uchwat dotyczacych opłaty za gospodarowanie odpadami komunalnymi. „Finanse Komunalne” 2013, nr 12, s. 31-42; A. Jezierska-Markocka, M. Markocki: Ustawa o utrzymaniu czystości i porządku... Legalis 2019, komentarz do art. 6j, nt. 1 . 
każdy miesiąc, w którym na danej nieruchomości zamieszkuje mieszkaniec ${ }^{18}$. $\mathrm{Z}$ kolei ustalenie zasad uregulowania opłaty także pozostawiono $\mathrm{w}$ gestii rady gminy, która na mocy uchwały stanowiącej akt prawa miejscowego określa termin, częstotliwość i tryb uiszczania opłaty ${ }^{19}$.

Wysokość opłaty zostaje ustalona na podstawie bezterminowej ${ }^{20}$ deklaracji składanej przez właściciela nieruchomości, zawierającej dane niezbędne w tym celu $^{21}$. W doktrynie wskazuje się, że część owych deklaracji pełni nie tylko funkcję fiskalną (wyliczenie wysokości należnej opłaty), ale również funkcje sprawozdawczo-kontrolne ${ }^{22}$. Tym samym składana deklaracja stanowi samoobliczenie wysokości opłaty przez zobowiązanego, a jednocześnie zawiera oświadczenia istotne dla powstania obowiązku jej zapłaty ${ }^{23}$.

\section{Opłata za gospodarowanie odpadami komunalnymi - podatek od śmieci czy opłata lokalna?}

Opisana powyżej konstrukcja opłaty za gospodarowanie odpadami komunalnymi sprawia, że jej charakter prawny budzi szereg kontrowersji. $Z$ jednej strony powiązanie opłaty z kosztami finansowania systemu gospodarowania mogłoby sugerować, że stanowi ona ekwiwalent za wykonanie przez gminę usług w zakresie gospodarowania odpadami komunalnymi, z drugiej zaś jej pobór jest niezależny od ilości odpadów wytwarzanych na danej nieruchomości, a nawet od faktycznego wytwarzania odpadów.

Nie ulega wątpliwości, że analizowane opłaty są przejawem danin publicznych $^{24}$, lecz problematyczna pozostaje ich kwalifikacja jako podatku, opłaty lub daniny o swoistym charakterze. Regulacje u.u.c.p.g. nie dają w tym zakresie jednoznacznej odpowiedzi; wskazują wyłącznie, że w sprawach dotyczących opłat za gospodarowanie odpadami komunalnymi stosuje się przepisy ustawy

18 Art. 6i ust. 1 pkt 1 u.u.c.p.g.

19 Art. 61 ust. 1 u.u.c.p.g.

20 Wyrok WSA w Gliwicach z dnia 22 września 2014 r., sygn. I SA/Gl 190/14, Legalis.

${ }^{21}$ A. Kiepas-Kokot: Utrzymanie porządku i czystości... Legalis 2017/el., komentarz do art. $6 \mathrm{~m}$, nt. I.1.

${ }^{22}$ G. Musolf: Charakter i zastosowanie deklaracji o wysokości opłaty za gospodarowanie odpadami komunalnymi na przykładzie województwa lubuskiego. „Przegląd Podatków Lokalnych i Finansów Samorządowych" 2013, nr 10, s. 10-18.

23 Wyrok WSA w Kielcach z dnia 26 czerwca 2014 r., sygn. I SA/Ke 265/14, Legalis.

${ }^{24}$ G. Radecki: Opłata za gospodarowanie..., s. 21; wyrok TK z dnia 28 listopada 2013 r., sygn. K 17/12 (Dz.U. 2013, poz. 1593), OTK-A 2013, nr 8, poz. 125; M. Cyrankiewicz: Opłata za odbiór śmieci jest danina publiczną. „Rzeczpospolita” PCD 2013, nr 10, s. 7; W. Fill: Podatek czy opłata za gospodarowanie odpadami? Serwis Prawo.pl, [online:] https://www.prawo. $\mathrm{pl} /$ samorzad/podatek-czy-oplata-za-gospodarowanie-odpadami,86001.html [dostęp: 10.03.2021]. 
z dnia 29 sierpnia 1997 r. - Ordynacja podatkowa ${ }^{25}$. Przyznają przy tym uprawnienia organów podatkowych wójtowi, burmistrzowi lub prezydentowi miasta, względnie zarządowi związku międzygminnego ${ }^{26}$ lub podmiotowi, któremu rada gminy udzieliła upoważnienia do załatwiania indywidualnych spraw z zakresu opłat za gospodarowanie odpadami komunalnymi w trybie art. 39 ust. 4 ustawy z dnia 8 marca 1990 r. o samorządzie gminnym ${ }^{27}$.

Powyższe przepisy nie rozstrzygają jednak charakteru opłaty za gospodarowanie odpadami komunalnymi jako podatku w rozumieniu art. 6 o.p. Słusznie wskazuje się bowiem, że owa opłata wymyka się klasycznemu podziałowi instrumentów prawnofinansowych na podatki, opłaty i ceny ${ }^{28}$.

$\mathrm{Z}$ jednej strony część przedstawicieli doktryny twierdzi, że skoro obowiązek uiszczania opłaty w zasadzie jest uzależniony od posiadania tytułu prawnego do nieruchomości, na której zamieszkują mieszkańcy (a nie od faktycznego powstawania odpadów) ${ }^{29}$, to opłata powinna być uznawana za zbliżoną charakterem do podatków lokalnych ${ }^{30}$. Podobne argumenty nawet stały się podstawą jej potocznej nazwy - ,podatek śmieciowy”31.

$\mathrm{Z}$ drugiej strony podkreśla się, że wynikające $\mathrm{z}$ art. 6r ust. 2 u.u.c.p.g. ścisłe powiązanie opłaty z pokrywaniem kosztów funkcjonowania systemu gospodarowania odpadami komunalnymi wskazuje na istnienie wzajemnych świadczeń gminy i właściciela nieruchomości ${ }^{32}$, przejawiające się w możliwości oczekiwania przez tego ostatniego od gminy realizacji obowiązku odbierania odpadów komunalnych ${ }^{33}$. O istnieniu owej wzajemności świadczeń może przekonywać dodatkowo fakt, że rada gminy w ustalaniu wysokości opłaty jest zobowiązana brać pod uwagę także koszty funkcjonowania systemu gospodarowania odpadami komunalnymi ${ }^{34}$. Tymczasem podatki z natury swej mają charakter nieodpłatny, przez co ich zapłacie nie towarzyszy wzajemny obowiązek świadczenia ${ }^{35}$.

${ }^{25}$ T.j. Dz.U. 2020, poz. 1325 ze zm.; dalej: o.p.

${ }^{26}$ Art. $6 \mathrm{q}$ ust. 1 u.u.c.p.g.

${ }^{27}$ Dz.U. 2020, poz. 713 ze zm.; art. 6q ust. 1a u.u.c.p.g.

${ }^{28}$ W. Fill: Podatek czy oplata...

${ }^{29}$ M. Paczocha: Ustawa o utrzymaniu czystości i porzadku w gminach a zasada przyzwoitej legislacji. „Finanse Komunalne” 2013, nr 7/8, s. 14.

${ }^{30}$ D. Kaczorkiewicz, B. Rutkowski: Charakter prawny opłaty za gospodarowanie odpadami komunalnymi $i$ konsekwencje niewywiązywania się z obowiązu jej ponoszenia. „Przegląd Podatków Lokalnych i Finansów Samorządowych" 2013, nr 12, s. 6-12.

${ }^{31}$ Zob. J. Jerzmański: Gospodarka odpadami komunalnymi - nowe zasady. „Przegląd Komunalny" 2011, nr 9, s. 86.

32 A. Jezierska-Markocka, M. Markocki: Komentarz do art. 6h Ustawy o utrzymaniu czystości i porzadku w gminach. Legalis 2019.

${ }^{33}$ G. Radecki, Oplata za gospodarowanie..., s. 21.

${ }^{34}$ Art. 6k ust. 2 pkt 3 u.u.c.p.g.

${ }^{35}$ Komentarz do art. 6 Ustawy Ordynacja Podatkowa. Red. H. Dzwonkowski. Legalis 2020/el., nb. 5. 
Stąd, wobec występowania elementu odpłatności, właściwsze w analizowanym przypadku wydaje się jednak określanie opłaty za gospodarowanie odpadami komunalnymi wskazanej $\mathrm{w}$ art. 6h u.u.c.p.g. właśnie mianem opłaty lokalnej $\mathrm{w}$ ujęciu konstytucyjnym ${ }^{36}$. Pogląd ten jest również prezentowany $\mathrm{w}$ orzecznictwie, w którym zaznacza się, że obowiązek ponoszenia przez właścicieli nieruchomości opłaty na rzecz gminy nie stanowi obowiązku podatkowego ze względu na jej odpłatnośćc ${ }^{37}$.

W ocenie autora należy zaakceptować powyższe stanowisko, czyli zakwalifikować opłatę za gospodarowanie odpadami komunalnymi jako opłatę lokalną. Brak jest wystarczających argumentów pozwalających na uznanie jej za podatek zgodnie z definicją wskazaną w art. 6 o.p. Pogląd ten nie wytrzymuje zwłaszcza testu nieodpłatności. Ustawowa konstrukcja opłaty - silnie akcentująca związek jej poboru $\mathrm{z}$ nałożonymi na gminę obowiązkami w zakresie gospodarki odpadami komunalnymi - pozwala przyjąć, że opłata za gospodarowanie odpadami komunalnymi ma charakter wzajemny, co wyraźnie odróżnia ją od podatku.

\section{Opodatkowanie opłaty za gospodarowanie odpadami komunalnymi podatkiem od towarów i usług}

\section{Wyłączenie opłaty za gospodarowanie odpadami komunalnymi spod opodatkowania podatkiem od towarów i usług}

Publicznoprawny charakter opłaty za gospodarowanie odpadami komunalnymi będzie wpływał również na kwestię jej opodatkowania podatkiem od towarów i usług. Stwierdzenie, że opłata ta nie powinna być uznana za podatek w rozumieniu art. 6 o.p., rodzi bowiem pytanie, czy ma ona - jako świadczenie przysługujące gminie w zamian za realizację ustawowych obowiązków w obszarze gospodarki odpadami komunalnymi - podlegać opodatkowaniu rzeczonym podatkiem.

Co do zasady zgodnie z art. 5 ust. 1 pkt 1 ustawy z dnia 11 marca 2004 r. o podatku od towarów i usług ${ }^{38}$ opodatkowaniu podlega również odpłatne

${ }^{36}$ W. Radecki: Komentarz do art. 6h Ustawy o utrzymaniu czystości i porzadku w gminach. LEX 2016; R. Dowgier: Czy do oplaty za gospodarowanie odpadami komunalnymi stosuje sie zasady dotyczace zaokraglania, o których mowa w art. 63 \$ 1 ordynacji podatkowej? Uwagi na tle wyroku WSA w Lublinie z 28.12.2012 r., (I SA/Lu 932/12). „Finanse Komunalne” 2013, $\mathrm{nr}$ 9, s. 44; A. Krzywoń: Opłata za gospodarowanie odpadami komunalnymi - niekonstytucyjna danina publiczna? „Przegląd Legislacyjny” 2011, nr 2/4, s. 11-16.

${ }^{37}$ Wyrok WSA w Gdańsku z dnia 2 lipca 2014 r., sygn. I SA/Gd 367/14, Legalis.

${ }^{38}$ T.j. Dz.U. 2021, poz. 106 ze zm.; dalej: u.VAT. 
świadczenie usług. Niemniej na podstawie art. 15 ust. 6 u.VAT nie uznaje się za podatnika organów władzy publicznej ani urzędów obsługujących te organy w zakresie zadań nałożonych odrębnymi przepisami prawa, do których realizacji zostały one powołane, $\mathrm{z}$ wyłączeniem czynności wykonywanych na podstawie zawartych umów cywilnoprawnych. Za organy władzy publicznej w rozumieniu art. 15 ust. 6 u.VAT należy uważać organy rządowej administracji centralnej, administracji terenowej (zarówno zespolonej, jak i niezespolonej) oraz organy administracji samorządowej ${ }^{39}$.

Wynika stąd, że kryterium decydującym o uznaniu organu władzy publicznej (w tym gminy) za podatnika VAT jest zachowywanie się nie jak organ władzy, lecz jak podmiot gospodarczy (przedsiębiorca) w stosunku do określonych transakcji lub czynności ${ }^{40}$. Zarazem nie można przyjmować, że o opodatkowaniu działań gminy podatkiem od towarów i usług przesądza sama odpłatność realizowanych zadań. Jeśli bowiem będą one zastrzeżone do wyłącznej kompetencji jednostki samorządu terytorialnego i przy ich wykonywaniu będzie ona korzystała z uprawnień władczych, działania takie nie będą kwalifikowane jako czynności podlegające opodatkowaniu rozpatrywanym tu podatkiem ${ }^{41}$.

Ze względu na powyższe w orzecznictwie wskazuje się, że gmina, pobierając opłaty za gospodarowanie odpadami komunalnymi, działa jako organ władzy publicznej, a nie wykonuje usług zwolnionych z podatku od towarów i usług ${ }^{42}$. Potwierdzają to również przedstawiciele doktryny ${ }^{43}$, zauważający, że omawiana opłata jako danina publiczna nie powinna w ogóle podlegać podatkowi od towarów i usług ${ }^{44}$.

Pogląd ten należy w pełni zaakceptować. Analiza istoty opłaty za gospodarowanie odpadami komunalnymi wskazuje jednoznacznie na jej publicznoprawny charakter jako daniny publicznej. Ze względu na wyłączne kompetencje gminy do realizacji omawianych obowiązków można stwierdzić, że opłata ta

${ }^{39}$ Wyrok WSA w Olsztynie z dnia 15 września 2005 r., sygn. I SA/Ol 278/05, Legalis; por. A. Bartosiewicz: Komentarz do art. 15 Ustawy o podatku od towarów i uslug. LEX 2020/el., nt. 53 .

${ }^{40}$ Por. m.in. wyrok WSA w Warszawie z dnia 27 lutego 2007 r., sygn. III SA/Wa 4312/06, LEX nr 234961; wyrok WSA w Warszawie z dnia 24 stycznia 2019 r., sygn. III SA/Wa 730/18, LEX nr 3060227.

${ }^{41}$ B. Rogowska-Rajda, T. Tratkiewicz: Działalność jednostek samorzadu terytorialnego jako organów władzy publicznej w świetle przepisów o podatku od towarów i usług. „Samorząd Terytorialny" 2018, nr 12, s. 66.

${ }^{42}$ Wyrok WSA w Rzeszowie z dnia 13 listopada 2012 r., sygn. I SA/Rz 968/12, LEX nr 1228893.

${ }^{43}$ J. Matarewicz: Wybrane praktyczne aspekty odzyskiwania VAT przez gminy. „Monitor Podatkowy” 2014, nr 8, s. 18; J. Budziszewski: Podatki w praktyce. „Doradztwo Podatkowe Biuletyn Instytutu Studiów Podatkowych” 2013, nr 2, s. 73-77; B. Rogowska-Rajda, T. Tratkiewicz: Dziatalność jednostek samorządu terytorialnego..., s. 66.

${ }^{44}$ D. Kaczorkiewicz, B. Rutkowski: Charakter prawny oplaty..., s. 6-12. 
mieści się w zakresie wykonywania zadań nałożonych na gminę na mocy prawa, wobec czego działalność gminy w tym obszarze nie powinna być uznawana za opodatkowaną podatkiem od towarów i usług.

Obecnie opłata będzie stanowiła należność publicznoprawną, dlatego też nie może ona stanowić części czynszu jako tzw. należność eksploatacyjna ${ }^{45}$. Kalkulując opłaty, gminy powinny uwzględniać podatek od towarów i usług, który zapłacą w cenie usługi odbierania śmieci świadczonej przez przedsiębiorców ${ }^{46}$.

\section{Problem opodatkowania podatkiem od towarów i usług opłaty przerzucanej na najemców}

Paradoksalnie, choć bezpośredni pobór przez gminę opłaty od właścicieli nieruchomości uznawany jest za czynność niepodlegającą podatkowi od towarów i usług, zupełnie inne skutki podatkowe mogą wystąpić wówczas, gdy opłata jest przerzucana z właściciela nieruchomości (w tym gminy, jej jednostki organizacyjnej lub spółki samorządowej) na najemcę. Niestety, orzecznictwo organów podatkowych okazuje się niejednolite - można tu spotkać dwa przeciwne stanowiska. Zgodnie z pierwszym opłata nie podlega opodatkowaniu podatkiem od towarów i usług również w razie przerzucenia jej przez właścicieli na najemców; stanowi bowiem odrębne od najmu świadczenie publicznoprawne i jako takie znajduje się poza zakresem VAT także wtedy, kiedy zostaje przeniesiona na najemcę $e^{47}$.

Natomiast drugi pogląd spotykany w bieżących interpretacjach indywidualnych głosi, że w przypadku przerzucenia opłaty na najemców powinna ona być uznawana za element wynagrodzenia $\mathrm{z}$ tytułu świadczonej usługi najmu (czynszu), a zatem - podlegać opodatkowaniu VAT według zasad właściwych dla usług najmu ${ }^{48}$. Opłata ta stanowi nieodłączny element owej usługi i należy ją traktować jako jedną usługę z najmem, o ile tylko wynajmujący decyduje się na przeniesienie jej kosztu na najemcę4.

Pogląd ten znajduje oparcie w dyspozycji art. 29a ust. 6 pkt 1 i 2 u.VAT, który stanowi, że podstawa opodatkowania obejmuje również podatki, cła, opłaty

${ }^{45}$ A.K. Modrzejewski: Właściciel i nieruchomość w świetle znowelizowanej ustawy o utrzymaniu czystości i porządku w gminach. „Samorząd Terytorialny” 2013, nr 1/2, s. 92.

${ }^{46}$ M. Cyrankiewicz: Nieopodatkowane, ale z VAT. „Rzeczpospolita” PCD 2013, nr 2, s. 25.

${ }^{47}$ Stanowisko to, dotyczące pobierania opłaty śmieciowej przez wspólnotę mieszkaniową od właścicieli lokali, potwierdza interpretacja indywidualna Dyrektora Krajowej Informacji Skarbowej z dnia 17 listopada 2020 r., sygn. 0114-KDIP4-2.4012.369.2020.2.MC. Legalis.

${ }^{48}$ Interpretacja indywidualna Dyrektora Krajowej Informacji Skarbowej z dnia 14 sierpnia 2019 r., sygn. 0115-KDIT1-1.4012.405.2019.1.AJ. Legalis.

${ }^{49}$ Interpretacja indywidualna Dyrektora Krajowej Informacji Skarbowej z dnia 14 sierpnia 2019 r., sygn. 0111-KDIB3-1.4012.224.2019.1.RSZ. Legalis. 
i inne należności o podobnym charakterze, $\mathrm{z}$ wyjątkiem kwoty podatku, oraz koszty dodatkowe, takie jak prowizje, koszty opakowania, transportu i ubezpieczenia, pobierane przez dokonującego dostawy lub usługodawcę od nabywcy lub usługobiorcy. Opłata za gospodarowanie odpadami komunalnymi traktowana jest tu na równi z innymi opłatami eksploatacyjnymi, a zatem - w zgodzie z wyrokiem Trybunału Sprawiedliwości Unii Europejskiej z dnia 16 kwietnia 2015 r. w sprawie C-42/14 - jako odrębna od usługi najmu wyłącznie wtedy, kiedy najemca ma możliwość wyboru świadczeniodawcy tej usługi ${ }^{50}$. Skoro zaś w aktualnym stanie prawnym wybór przedsiębiorcy odbierającego odpady komunalne pozostaje w gestii gminy, brak jest uzasadnienia do wyłączania opłaty z podstawy opodatkowania najmu i stosowania do niej odmiennych reguł opodatkowania niż do głównej usługi najmu ${ }^{51}$. Pewnym pocieszeniem może być tu okoliczność, że w przypadku wynajmu na cele mieszkaniowe czynność ta będzie zasadniczo podlegała zwolnieniu z podatku od towarów i usług ${ }^{52}$.

Według autora należy się opowiedzieć za pierwszym poglądem. Przyjęcie odmiennej koncepcji prowadzi do nieuzasadnionego zróżnicowania sytuacji właścicieli nieruchomości i sytuacji najemców; koncepcja ta nie daje się również pogodzić z art. 2 ust. 2a u.u.c.p.g., na podstawie której właściciel z najemcą mogą wskazać umownie podmiot obowiązany do wykonywania obowiązków wynikających z u.u.c.p.g., w tym w zakresie regulowania opłaty.

Jak się zatem wydaje, w razie obciążenia najemcy obowiązkiem uiszczenia opłaty trzeba by uznać, że nie tyle stanowi ona element kalkulacyjny wynagrodzenia należnego wynajmującemu, ile najemca staje się podmiotem bezpośrednio odpowiedzialnym za jej zapłatę. W tym przypadku zaś opłata nie traci swojego publicznoprawnego („,daninowego") charakteru i wciąż nie powinna być opodatkowana podatkiem od towarów i usług.

Występowanie w orzecznictwie dwóch sprzecznych ze sobą poglądów zasługuje na negatywną ocenę. De lege ferenda należałoby zatem postulować jednoznaczne uregulowanie wskazanej kwestii w ustawie lub wydanie przez Ministra Finansów interpretacji ogólnej, która usunęłaby rozbieżności w orzecznictwie organów podatkowych i dała podstawę do wypracowania jednolitej praktyki orzeczniczej.

${ }^{50}$ Por. też interpretacja indywidualna Dyrektora Krajowej Informacji Skarbowej z dnia 7 czerwca 2017 r., sygn. 0115-KDIT1-1.4012.196.2017.1.BK. Legalis.

${ }^{51}$ Por. też interpretacja indywidualna Dyrektora Izby Skarbowej w Bydgoszczy z dnia 31 października 2016 r., sygn. ITPP1/4512-533/16-2/MS. Legalis.

${ }^{52}$ Art. 43 ust. 1 pkt 36 u.VAT. 


\section{Podsumowanie}

Opłata za gospodarowanie odpadami komunalnymi pozostaje ściśle związana $\mathrm{z}$ nałożonymi na gminy obowiązkami $\mathrm{w}$ zakresie gospodarowania owymi odpadami i ma stanowić swoisty ekwiwalent kosztów funkcjonowania tego systemu. Należy bez wątpienia uznać ją za daninę publiczną, jednak sporny jest jej charakter jako podatku lub opłaty w rozumieniu konstytucyjnym. Element odpłatności i bezpośredniego powiązania z realizacją przez gminy wspomnianych obowiązków wskazuje, że analizowana opłata nie powinna być traktowana jako podatek. Gmina, zajmując się gospodarowaniem odpadami komunalnymi, działa jako organ publiczny realizujący swoje ustawowe zadania i w efekcie nie może być w tym zakresie uznana za podatnika VAT. Stąd opłata nie powinna podlegać opodatkowaniu podatkiem od towarów i usług, co potwierdza istota opłaty za gospodarowanie odpadami komunalnymi jako daniny publicznej.

Niemniej wiele problemów interpretacyjnych sprawia kwestia przerzucania opłaty na najemców. Orzecznictwo organów podatkowych pozostaje w tym względzie niejednolite. Część organów uznaje, że opłata jako danina publiczna również $\mathrm{w}$ tej sytuacji nie powinna być opodatkowana VAT, natomiast $\mathrm{w}$ orzecznictwie innych wskazano na potrzebę zaliczania opłaty do podstawy opodatkowania VAT. Różnicowanie zasad w zależności od tego, czy opłata jest pobierana bezpośrednio od właściciela, czy przerzucana na najemcę, nie znajduje uzasadnienia i nie jest pożądane. Stąd należy postulować de lege ferenda sprecyzowanie tej kwestii bezpośrednio w ustawie lub wydanie przez ministra finansów interpretacji ogólnej, która usunęłaby rozbieżności i ukierunkowała linię orzeczniczą.

\section{Literatura}

Bartosiewicz A.: VAT. Komentarz. LEX 2020.

Błachut M.: Wybrane problemy stanowienia aktów prawa miejscowego, dotyczacych opłaty za gospodarowanie odpadami komunalnymi. „Nowe Zeszyty Samorządowe” 2013, nr 1, s. 1-2.

Budziszewski J.: Podatki w praktyce. „Doradztwo Podatkowe. Biuletyn Instytutu Studiów Podatkowych" 2013, nr 2, s. 73-77.

Cyrankiewicz M.: Nieopodatkowane, ale z VAT. „Rzeczpospolita” PCD 2013, nr 2.

Cyrankiewicz M.: Opłata za odbiór śmieci jest danina publiczną. „Rzeczpospolita” PCD 2013, nr 10.

Dowgier R.: Czy do opłaty za gospodarowanie odpadami komunalnymi stosuje się zasady dotyczace zaokraglania, o których mowa w art. 63 \& 1 ordynacji podatkowej? Uwagi na tle 
wyroku WSA w Lublinie z 28.12.2012 r. (I SA/Lu 932/12). „Finanse Komunalne” 2013, nr 9, s. 41-45.

Fill W.: Podatek czy opłata za gospodarowanie odpadami?. 31.10.2012, Serwis Prawo.pl, [online:] https://www.prawo.pl/samorzad/podatek-czy-oplata-za-gospodarowanie-odpadami,86001. html [dostęp: 10.03.2021].

Gawrońska K.: Kompetencje rady gminy w zakresie zmiany uchwat dotyczacych opłaty za gospodarowanie odpadami komunalnymi. „Finanse Komunalne” 2013, nr 12, s. 31-42.

Hadel M.: Podmiot zobowiazany do ponoszenia opłat za gospodarowanie odpadami komunalnymi. Glosa aprobująca do wyroku Wojewódzkiego Sądu Administracyjnego w Poznaniu z dnia 21 listopada 2018 r., I SA/Po 510/18. „Finanse Komunalne” 2019, nr 9, s. 66-78.

Jerzmański J.: Gospodarka odpadami komunalnymi - nowe zasady. „Przegląd Komunalny” 2011, nr 9, s. 83-98.

Jezierska-Markocka A., Markocki M.: Ustawa o utrzymaniu czystości i porządku w gminach. Komentarz. Legalis 2019.

Kaczorkiewicz D., Rutkowski B.: Charakter prawny opłaty za gospodarowanie odpadami komunalnymi i konsekwencje niewywiązywania się z obowiązku jej ponoszenia. „Przegląd Podatków Lokalnych i Finansów Samorządowych" 2013, nr 12, s. 6-12.

Kiepas-Kokot A.: Utrzymanie porzadku i czystości w gminie. Gospodarowanie odpadami komunalnymi. Komentarz. Legalis 2017.

Krzywoń A.: Opłata za gospodarowanie odpadami komunalnymi - niekonstytucyjna danina publiczna?. „Przegląd Legislacyjny” 2011, nr 2/4, s. 11-23.

Matarewicz J.: Wybrane praktyczne aspekty odzyskiwania VAT przez gminy. „Monitor Podatkowy" 2014, nr 8, s. 18-24.

Modrzejewski A.K.: Właściciel i nieruchomość w świetle znowelizowanej ustawy o utrzymaniu czystości i porzadku w gminach. „Samorząd Terytorialny” 2013, nr 1/2, s. 88-98.

Musolf G.: Charakter i zastosowanie deklaracji o wysokości opłaty za gospodarowanie odpadami komunalnymi na przykładzie województwa lubuskiego. „Przegląd Podatków Lokalnych i Finansów Samorządowych" 2013, nr 10, s. 10-18.

Ordynacja podatkowa. Komentarz. Red. H. Dzwonkowski. Wydawnictwo C.H. Beck, Warszawa 2020.

Paczocha M.: Ustawa o utrzymaniu czystości i porzadku w gminach a zasada przyzwoitej legislacji. „Finanse Komunalne” 2013, nr 7/8, s. 5-24.

Radecki G.: Opłata za gospodarowanie odpadami komunalnymi. „Przegląd Prawa Publicznego” 2012, nr 12, s. 19-37.

Radecki W.: Utrzymanie czystości i porządku w gminach. Komentarz. Warszawa 2016.

Rogowska-Rajda B., Tratkiewicz T.: Działalność jednostek samorzadu terytorialnego jako organów władzy publicznej w świetle przepisów o podatku od towarów i ustug. „Samorząd Terytorialny" 2018, nr 12, s. 59-67.

Szwaczko W.: Kto jest właścicielem nieruchomości?. „Przegląd Komunalny” 2011, nr 10, s. $34-35$.

Zarządzanie nieruchomościami. Red. Z. Bukowski. Wolters Kluwer, Warszawa 2013.

Orzecznictwo

Wyrok TK z dnia 28 listopada 2013 r., sygn. K 17/12 (Dz.U. 2013, poz. 1593), OTK-A 2013, nr 8, poz. 125 .

Wyrok WSA w Gdańsku z dnia 2 lipca 2014 r., sygn. I SA/Gd 367/14, Legalis.

Wyrok WSA w Gliwicach z dnia 22 września 2014 r., sygn. I SA/Gl 190/14, Legalis.

Wyrok WSA w Kielcach z dnia 26 czerwca 2014 r., sygn. I SA/Ke 265/14, Legalis. 
Wyrok WSA w Olsztynie z dnia 15 września 2005 r., sygn. I SA/Ol 278/05, Legalis.

Wyrok WSA w Poznaniu z dnia 21 listopada 2018 r., sygn. I SA/Po 510/18, LEX nr 2587089.

Wyrok WSA w Rzeszowie z dnia 13 listopada 2012 r., sygn. I SA/Rz 968/12, LEX nr 1228893.

Wyrok WSA w Warszawie z dnia 24 stycznia 2019 r., sygn. III SA/Wa 730/18, LEX nr 3060227.

Wyrok WSA w Warszawie z dnia 27 lutego 2007 r., sygn. III SA/Wa 4312/06, LEX nr 234961.

Interpretacje indywidualne

Interpretacja indywidualna Dyrektora Izby Skarbowej w Bydgoszczy z dnia 31 października 2016 r., sygn. ITPP1/4512-533/16-2/MS, Legalis.

Interpretacja indywidualna Dyrektora Krajowej Informacji Skarbowej z dnia 17 listopada 2020 r., sygn. 0114-KDIP4-2.4012.369.2020.2.MC, Legalis.

Interpretacja indywidualna Dyrektora Krajowej Informacji Skarbowej z dnia 14 sierpnia 2019 r., sygn. 0115-KDIT1-1.4012.405.2019.1.AJ, Legalis.

Interpretacja indywidualna Dyrektora Krajowej Informacji Skarbowej z dnia 14 sierpnia 2019 r., sygn. 0111-KDIB3-1.4012.224.2019.1.RSZ, Legalis.

Interpretacja indywidualna Dyrektora Krajowej Informacji Skarbowej z dnia 7 czerwca 2017 r., sygn. 0115-KDIT1-1.4012.196.2017.1.BK, Legalis.

Bartosz Kubista

\title{
Legal and tax characteristics of the municipal solid waste management fee and VAT taxation thereof
}

\author{
Summary
}

The article deals with the subject of the municipal waste management fee, including the structural elements of the fee and the rules of its collection. The author also qualifies the fee as a public levy and assesses whether it is closer to a fee in the constitutional sense, or a tax. The article also refers to the issue of tax consequences of the fee in the tax on goods and services.

Key words: municipal waste management fee, municipal waste, value added tax, fees

\section{Бартош Кубиста}

\section{Налогово-правовая характеристика сбора за управление коммунальными отходами и взимание с него налога на товары и услуги}

Резюме

В статье рассматривается проблематика сбора за управление коммунальными отходами, составные элементы сбора и правила его взимания. В статье также квалифицируется сбор как государственная дань и оценивается, ближе ли он к оплате в трактовке конститу- 
ции или все-таки к налогу. В статье также рассматривается вопрос налоговое бремя сбора в виде налога на товары и услуги.

Ключевые слова: сбор за управление коммунальными отходами; коммунальные отходы; налог на товары и услуги; сборы

\section{Bartosz Kubista}

\section{Caratteristiche legali e fiscali della tassa per gestione dei rifiuti urbani e la sua tassazione con la tassa sui beni e servizi}

\section{Sommario}

L'articolo tratta il tema della tassa per la gestione dei rifiuti urbani, compresi gli elementi strutturali della tassa e le regole della sua raccolta. L'articolo qualifica anche la tassa come un prelievo pubblico e valuta se è più vicino alla tassa nel senso costituzionale, o una tassa. L'articolo si riferisce anche alla questione delle conseguenze fiscali di un'imposta sui beni e servizi.

Parole chiave: tassa per la gestione dei rifiuti urbani; rifiuti urbani; imposta su beni e servizi; tasse 